\title{
IMPACTS OF SARS-COV-2 ON BRAZILIAN AGRIBUSINESS
}

\author{
Jadson Belem de Moura $^{1}$ \\ Rodrigo Fernandes de Souza ${ }^{2}$
}

\section{Summary}

The pandemic caused by the Sars-Cov-2 virus has impacted several sectors of the world's economy including agribusiness. In Brazil, the quarantine decreed by political leaders in order to contain the spread of Covid-19 mainly affected the productive sectors of the medium and small producer, which ended up reflecting directly on the price of food of the final consumer. Sectors such as transportation, distribution and agro-industry should also present a deficit because they are productive activities with agglomerations of people who have had their work regimes changed. However, the extensive production sector benefited from the rising dollar and increased demand for food and exports from China, and this demand may extend in the medium and long term. There is a great possibility that agribusiness will be the sector with the largest surplus in the Brazilian economy in the coming years and be responsible for balancing the trade balance in the post-recession period.

Keywords: Covid-19, coronavirus, globalization, agriculture, pandemic, food security,

The pandemic outbreak caused by the Sars-Cov-2 virus hit the world unexpectedly and massively, causing collapses in the health system and disruption in the economic and social system (Lai et al. , 2020). Although Covid-19 presents a higher risk for those infected with pre-existing comorbidities, its lethality is relatively low, leading to death of about $1 \%$ of infected people (Zhou et al. , 2020), however, its biggest problem is the rapid speed of dissemination, which led to the collapse of the health system of countries such as Italy, Spain and Iran in a matter of days (Tuite et al. , 2020) .

The complications that the pandemic brought to the nations not only affected the health systems, but also hit the economic system intensely. A very effective measure against the spread of Sars-Cov-2 is social isolation (Niu \& Xu, 2020), a measure adopted by most countries affected by the virus. In this situation, only essential services such as markets, pharmacies and hospitals were allowed to operate. Hard-hit regions decreed outbreak, as in Lombardy in Italy (Grasselli et al. , 2020). The economic recession

\footnotetext{
1 PhD in Soil Microbiology - Evangelical College of Goianésia- jadsonbelem@gmail.com

2 PhD student in Natural Resources of the Cerrado- State University of Goiás.
} 
cannot yet be measured, but it is estimated that some countries will have greater difficulties, such as Portugal, Spain and Greece (Fernandes, 2020)..

In Brazil, the first confirmed case of Covid-19 was diagnosed on February 26, 2020 in the state of São Paulo, reaching the number of 15,927 cases on April 8, with 800 deaths (Ministry of Health, 2020). The states and municipalities have taken protectionist measures, declaring social isolation in order to contain the spread of the virus and prevent the collapse of the health system.

Agribusiness is one of the main economic activities of the country in the last two decades, which maintained the surplus of Brazil's financial activities was agribusiness (Pacheco, 2019). Food production is considered an essential service sector and, in theory, could not be stopped due to covid-19 quarantine determinations.

However, a more detailed look at the various agribusiness sectors and their particularities is essential to then analyze the effects of the crisis caused by the Sars-Cov2 virus. Some sectors have felt the impact more, especially those that rely more on third parties who are directly on the state's outbreak orders. Although it is still too early to measure such effects, it is observed that the price of food recorded an inflation in March $36 \%$ higher in 2020 than in 2019 and sectors such as vegetable production, milk and beef cattle are directly linked to these indices (FGV, 2020). The family farming sector was severely hit with the prohibition of agglomerations by municipal and state decrees with the suspension of free fairs bringing, above all, social disturbances.

On the other hand, some agricultural products marketed in Brazil are imported mostly from countries such as China and Spain. Imports of Chinese garlic, for example, moved US\$73.3 million in 2019 (Agrostat, 2020). In the current world situation, China has reduced port activities by $96 \%$, mainly by reducing labor at ports. On average, 50,000 containers are moved daily in Chinese ports, with the pandemic reaching 2,000 containers per day. This difficulty in importing can cause the production and commercialization of national garlic to be increased, favoring Brazilian producers.

On the other hand, the extensive production sector benefited from the crisis outlook due to the high dollar and the high demand for food in the Chinese market, including futures contracts at attractive prices, demonstrating a medium and long-term outlook 
favorable to grain exports (Oxford Analytica, 2020). Soybean showed a $40 \%$ increase compared to March 2019. Other commodities such as corn, cotton, coffee and orange also increased in this period.

Another worrying aspect that involves food production is rational and sustainable consumption and distribution. In crisis situations, the population fearing food shortages, depletes market stocks causing shortages, this increase in demand causes an increase in prices triggering inflation, a behavior observed in previous pandemics. Rational consumption is fundamental to the sustainability of the economic system (Siche, 2020)..

In a previous analysis, agribusiness suffers little influence from the crisis caused by the Sars-Cov-2 virus. The food production sector, besides being essential, is an activity of low agglomeration and people, which explains the low impact of Covid-19. This puts Brazil in a strategic position of economic recovery.

To better understand this position, it is necessary to take as north the study of Correia et al. , (2020) that evaluated the posture of different cities in the United States during the Spanish Flu Surte in the 10's. In this study, he compared the economic recovery of cities that adopted the posture of total isolation of the population to contain the disease, partial isolation, and cities that did not adopt protective measures and found that, even under recession, cities that adopted severe protective measures had a period of faster economic recovery.

The current Brazilian scenario fits this conclusion because agribusiness can play a fundamental role in the country's economic recovery (Pacheco, 2019). In this sense, Brazil does not owe in any sense to other countries in technology and labor, being competitive in its products in quality and price, with the advantage that still has the ability to expand production and own the largest agricultural barn in the world (Moura \& Cabral, 2019).

It is still too early to conclude because there is much to observe about the pandemic and the economic scenario of agribusiness in Brazil and in the world, but the importance of understanding the impact of Covid-19 and its social and economic outbreak on the various productive sectors and their reflections on society is indisputable. 


\section{References}

Agrostat. Estatísticas de Comércio Exterior do Agronegócio Brasileiro. Disponível em http://indicadores.agricultura.gov.br/agrostat/index.htm

Agrostat. 2020. AGROSTAT - Estatisticas de Comércio Exterior do Agronegócio Brasileiro.

Correia S, Luck S, Verner E. 2020. Pandemics Depress the Economy, Public Health Interventions Do Not: Evidence from the 1918 Flu. Rochester, NY: Social Science Research Network.

Fernandes N. 2020. Economic Effects of Coronavirus Outbreak (COVID-19) on the World Economy. Rochester, NY: Social Science Research Network.

FGV. 2020. Portal da Inflação.

Grasselli G, Pesenti A, Cecconi M. 2020. Critical Care Utilization for the COVID-19 Outbreak in Lombardy, Italy: Early Experience and Forecast During an Emergency Response. JAMA.

Lai C-C, Shih T-P, Ko W-C, Tang H-J, Hsueh P-R. 2020. Severe acute respiratory syndrome coronavirus 2 (SARS-CoV-2) and coronavirus disease-2019 (COVID-19): The epidemic and the challenges. International Journal of Antimicrobial Agents 55: 105924.

Ministério da Saúde. 2020. Coronavírus Brasil.

Moura JB, Cabral JSR. 2019. Mycorrhizas in Central Savannahs: Cerrado and Caatinga. In: Pagano MC, Lugo MA, eds. Fungal Biology. Mycorrhizal Fungi in South America. Cham: Springer International Publishing, 193-202.

Niu Y, Xu F. 2020. Deciphering the power of isolation in controlling COVID-19 outbreaks. The Lancet Global Health 8: e452-e453.

Oxford Analytica. 2020. China prioritises food security amid COVID-19 outbreak. Emerald Expert Briefings oxan-db.

Pacheco CF. 2019. Análise do desempenho dos produtos agrícolas na balança comercial brasileira no período de 2010 a 2015. Revista Eletrônica de Debates em Economia 7.

Siche R. 2020. What is the impact of COVID-19 disease on agriculture? Scientia Agropecuaria 11: 3-6.

Tuite AR, Bogoch I, Sherbo R, Watts A, Fisman DN, Khan K. 2020. Estimation of COVID-2019 burden and potential for international dissemination of infection from Iran. medRxiv: 2020.02.24.20027375. 
Zhou F, Yu T, Du R, Fan G, Liu Y, Liu Z, Xiang J, Wang Y, Song B, Gu X, et al. 2020. Clinical course and risk factors for mortality of adult inpatients with COVID-19 in Wuhan, China: a retrospective cohort study. The Lancet 395: 1054-1062. 